\section{Dr. J. D. Comrie}

Dr. John Dixon Comrie, a well-known Edinburgh physician and medical historian, whose death took place on October 2, was born on February 28, 1875, the son of Dr. J. D. Comrie. Ho was educated at Georgo Watson's Academy and the University of Edinburgh, whero he qualified MI.B. with first-class honours in 1899, becoming F.R.C.P. (Edin.) in 1906 and II.D. in 1911. After holding resident appointments at the Edinburgh and Glasgow Infirmaries, he attended post-graduate courses in Berlin and Vienna, and was clinical assistant at the National Hospital, Queen Square, London, before settling in practice at Edinburgh, where he successively became pathologist, assistant physician and full physician to the Royal Infirmary as well as consulting physician to the Deaconess Hospital and the Princess Mrargaret Rose Hospital for Crippled Children, Fairmilehead, Edinburgh. During the War of 1914-18 he was consulting physician to the North Russian Expeditionary Force, with the rank of Lieutenant-Colonel, R.A.M.C.

Dr. Comrie's literary output was considerable. In addition to his principal work entitled "Tho History of Scottish Medicine", of which the first edition appeared in 1927, and the second, enlarged to two volumes, in 1932, he contributed many articles on medico-historical subjects to the British Medical Journal, Edinburgh MIedical Journal, Archiv für Geschichte der Medizin and the Proceedings of the International Society of the History of Medicine, at the congresses of which he was a well-known figure. In recognition of his valuable work on medical history he was appointed reader in the history of medicine in the University of Edinburgh, honorary fellow of the Italian Society of the History of Medical Science, and president of the Section of the History of Nedicino at the meetings of the British Nedical Association at Edinburgh in 1927 and Winnipeg in 1930.

In addition to his original work and his consulting practice, Dr. Comrie was frequently engaged in an editorial capacity, being editor of the Edinburgh Series of Medical Text-books, the selected works of T. Sydenham, Black's "NIedical Dictionary", and since 1938 of the Edinburgh Medical Journal. His unfailing courtesy and kindness endeared him to all who knew him and particularly his co-workers, by whom ho was elected vice-president of the Royal College of Physicians of Edinburgh, chairman of the Scottish Committee of the British Mredical Association, and president of the Royal Nedical Society of Edinburgh.

J. D. Rolleston.

\section{Dr. Walther Horn}

Tue death of Dr. Walther Horn on July 10 last in his sixty-eighth year removes a familiar personality from the world of entomology. Although essentially a worker in taxonomy who held very definite views on its principles, his interests covered a wider field, and he worked for the good of entomology as a whole.
A very regular attendant and contributor at international congresses, Horn becams personally known to a wide circle of European and Amorican entomologists. For nearly fifty years he was a student of the Coleoptera, becoming the world authority on the family Cicindelidx. A few years before the War of 1914-18 he becamo director of the nowly founded Deutsches Entomologisches National-Niuseum in Dahlem, and devoted great energy in bringing it up to its present status and efficiency. The Museum suffered a severe setback by the advent of the War. Horn was called up for military service and, in this period, he exercised his original profession of a doctor. During the supervening period of inflation, the funds of his Museum dwindled away, and it was only by his untiring courage that things were kopt together. By soliciting small sums from his friends in other lands, and by taking advantago of favourable monetary changes, he gradually acquired the means of saving his Museum from ruin. In 1921 its character underwent change and its namo was altered to that of the Deutsches Entomologisches Institut, with affiliation to the Kaiser-Wilhelm Gesollschaft in Berlin. Its primary function becamo bibliographical rather than the maintenance of collections.

At the time of his death, Horn, in collaboration with Dr. Hans Sachtleben, edited threo periodicals which were extensively used as a medium for procuring current literature for the Instituto by way of exchange. During 1935-37 the publication of Horn's "Entomologische Sammlungen" was a notable effort wherein he recorded the history of all scientifically important insect collections from the time of I,innaus onwards.

Horn's singleness of purpose, coupled with wide travel, linguistic ability and cordiality towards men of all nations, made him many friends. He was able to free himself from some of the binding force of national limitations and, thereby, played a part in promoting international amity among co-workers that will be hard to replace.

A. D. Tммs.

WE regret to announco the following deaths:

Dr. Arthur P. Beddard, chairman of the Pharmacopœia Commission, formerly lecturer in medicino in Guy's Hospital, London.

Prof. R. A. Craig, professor of veterinary science in Purdue University, an authority on the diseases of pigs, on October 12, aged sixty-soven years.

MIr. J. A. Fulton, director of the Mackay School of Mines of the University of Nevada, on October 9, aged sixty-one years.

Prof. H. O. Knight, professor of anatomy in the University of Texas, an authority on the anstomy of the hand and foot, on October 5, aged fifty-eight years.

Dr. R. A. Sampson, F.R.S., astronomer-royal for Scotland during 1910-37, formerly professor of mathematics and astronomy in the University of Durham, on November 7, aged seventy-three years. 